\title{
Fiandografia: entre bordados, leituras, escritas... experimentações, numa pesquisa em educação
}

Thread-writing: among embroidering, readings, writings... experimentations in a research in education

Alice Copetti Dalmasoi

Universidade Federal de Santa Maria

\section{Resumo}

Trato nesse artigo de expor o recorte de uma pesquisa de doutorado em educação que se constituiu de experimentações entre leituras e escritas. A Fiandografia, nome dado a esse processo, procurou pensar e operar modos de escrileituras, cujas materialidades passaram a envolver a co-habitação de linhas, bordados, cores, aproximações com teias e aranhas: devires-animal, mulher, criança, múltiplos e imperceptíveis. Fiandar, verbo criado para movimentar a construção das relações entre leitura e escrita, compôs uma trama-tecido, passível e aberta, que foi dando corpo à pesquisa, como um caminho, um tracejar-tecer-costurar fios de escrita numa pesquisa em educação. O que pode uma Fiandografia? Um pouco sobre desorganizar as ideias, a obrigatoriedade de uma pesquisa, certezas e determinações sobre os usos da linguagem. Portanto, um movimento de desaprender no próprio percurso do processo. Desaprender sobre modos de ler, de escrever, de ser, falar, sentir e pensar em educação.

Palavras-chave: Escrita; Leitura; Fiandografia; Pesquisa em educação.

\begin{abstract}
I present in this paper part of a doctorate research in Education, which is constituted by experimentations between readings and writings. The Thread-writing, name given to this process, aimed at thinking and operating ways of writreadings, whose materiality involved the cohabiting of threads, embroidering, colors, approximation with webs and spiders: becoming multiple and imperceptible animals, women, children. Thread-write, verb created to move the construction of relations between reading and writing, composed a capable and open weave-fabric/texture that gives body to the research as a path, a trace-weave-sewing of writing threads in a research in Education. What can a Thread-writing do? A little on disorganizing ideas, the compulsory requirement of a research, certainties and determinations about the uses of language. Therefore, a movement of unlearning along the very own process. Unlearning about ways of reading, writing, being, speaking, feeling, and thinking Education.
\end{abstract}

Keywords: Writing; Reading; Thread-writing; Research in Education.

Revista Digital do LAV - Santa Maria - vol. 9, n. 2, p. 7 - 27. - mai./ago. 2016 ISSN 1983 - 7348 http://dx.doi.org/10.5902/1983734823503 


\section{Vasculhar sentidos de uma pesquisa: um convite}

- Por que escreves?

- Porque preciso dar sons pros gritos que não quero ouvir...

- Mas, e ouves, quando escreves?

- Ouço. Ouço os que gritam dentro de mim, que não pertencem a mim.

- Me explica melhor.

- Não é um eu que me traduz. Sou feito de tantas coisas que digo ser minhas. Você também. As crenças e sonhos que carrego não são meus. São parte, somente parte, de algo que está aquém e além de mim. Então escrevo para que essas coisas vazem, para que as palavras soergam essas coisas que não são minhas. Porque, à medida que escrevo, surge o modo como ando pelo mundo e aquilo que ainda não me tornei e que, com a escrita, me torno (DALMASO, 2016, p. 45).

Talvez os leitores do presente relato da pesquisa de doutorado ${ }^{1}$ que aqui apresento possam atravessar uma ponte, como um convite que alguém faz, a uma visita. Não há pretensão, nesse convite, de assimilação ou de exclusão de olhares ou de linguagens. A ponte não comunica mundos, porque leitor e escritor não se identificam, nem se igualam, nem se homogeneízam. Quiçá, ambos, possamos nos transformar, posto que, tudo que nos cerca nesse percurso e travessia, é diferença (VEIGA-NETO, 2004).

As intenções aqui circulam em compartilhar o percurso de uma pesquisa, a qual, desde sempre, procurou investir na produção de escrileituras (CORAZZA, 2013) que não estivessem em falta com alguém ou alguma coisa, uma proposta ou, especificamente, o ideal de um texto, de uma pesquisa, de um sujeito.

Relatar parte considerável de um percurso onde a pesquisadora investiu (e permanece investindo, posto que uma pesquisa nunca cessa de se atualizar e se tornar outra coisa) em aprender sobre o movimento de dar-se o direito de ler e escrever pelo prazer desses movimentos. E do que pode, com e a partir disso, estabelecer alianças com a educação. Linguagens - da literatura que utilizei, das leituras desse processo e das outras composições de escritas que fui trazendo à pesquisa - que não desejaram comunicar, criar consensos, fazer refletir sobre educação. Apresentaram, por isso, certo caráter de inutilidade em criar consensos educacionais. A pesquisa tratou de descrever um percurso, um modo, um processo de encontro e experimentação com a escrita e com a leitura e de operação com as mesmas. O que motivava e levava a estudar era essa "linguagem inútil", que se destitui de construir uma verdade contingente e moral, para, quem sabe, "sofrer menos" (BARTHES, 2004, p. 142).

\footnotetext{
1 Relativo à Tese de Doutorado em Educação defendida em abril de 2016 e intitulada Fiandografia: experimentações entre leitura e escrita numa pesquisa em educação.
}

Revista Digital do LAV - Santa Maria - vol. 9, n. 2, p. 7 - 27. - mai./ago. 2016 ISSN 1983 - 7348 http://dx.doi.org/10.5902/1983734823503 
Intentei em produzir sulcos na ideia de linguagem exclusivamente considerada "como um suporte (de significado), como um instrumento (de expressão, de comunicação) ou como veiculo (de informação)" (LARROSA, 2004, p. 299). Ou seja, procurei tratar a linguagem ao modo como os autores que utilizei também a usavam, de modo não soberanamente objetivante e instrumental, mas como experiência e experimentação, na relação com ela e de seu desfrute, numa certa desenvoltura erótica com o texto que se lê e se escreve, ao procurar operar a instância de "fazer passar a experimentação e o desejo pela relação com o texto, não só a compreensão ou o sentido" (LARROSA, 2004, p. 303).

$\mathrm{Na}$ perspectiva de uma experimentação, a paisagem da pesquisa (ou mesmo da construção de um texto, de um artigo, aula) vai sendo feita por arranjos, maquinações e o percurso não é outra coisa do que essas conexões que vão sendo inventadas, não importando tanto o que os elementos juntados significam, tampouco o que vai acontecer ou qual o próximo passo. Interessa mais "mobilizar o corpo, o pensamento, sensibilizálos de modo que cada um experimente a paisagem, faça conexões, traçando linhas e acompanhando-as, linhas por meio das quais a paisagem se desmancha e se inventa" (GODOY, 2007, p. 135).

Nessa paisagem, as leituras sobre conceitos de escrita e leitura a partir de Barthes (2004, 2008, 2012), Deleuze (1997, 2013), Larrosa (2004, 2010, 2014), empurram com força o trabalho. No entanto, os conceitos de devir (DELEUZE; GUATTARI, 1995, 1996, 1997) e acontecimento (DELEUZE, 2003; DELEUZE; PARNET, 1998) aparecem e ocupam também seu lugar na pesquisa, atrelados ao processo de experimentação com a escrita e com as leituras, ainda que não se disserte sobre cada um deles. Conceitos que dão fôlego aos dados, à Fiandografia (nome criado para definir esse modo de pesquisar), construindo, tomando corpo junto a ela, efetuando-se como um caminho, um tracejar, um criar fios de escrita numa pesquisa.

Poder ir inventando, roubando histórias, falas, escritos, um fiar de linhas que dilui o sujeito que escreve. Conexões entre personagens, contos, escritos pessoais, dos outros, oralidades presentes na vida, que desejou se construir num tear de fios... tecer fios de palavras... por arte.

A ponte está aí, leitor.

\section{A infinita fiadeira (e sobre uma Fiandografia)}

A aranha, aquela aranha, era tão única: não parava de fazer teias! Fazia-as de todos os tamanhos e formas. Havia, contudo, um senão: ela fazia-as, mas não lhe dava utilidade. O bicho repaginava o mundo. Contudo, sempre inacabava as suas obras. Ao fio e ao cabo, ela já amealhava uma porção de teias que só ganhavam senso no rebrilho das manhãs.

Revista Digital do LAV - Santa Maria - vol. 9, n. 2, p. 7 - 27. - mai./ago. 2016 ISSN 1983 - 7348 http://dx.doi.org/10.5902/1983734823503 
E dia e noite: dos seus palpos primavam obras, com belezas de cacimbo gotejando, rendas e rendilhados. Tudo sem fim nem finalidade. Todo o bom aracnídeo sabe que a teia cumpre as fatais funções: lençol de núpcias, armadilha de caçador. Todos sabem, menos a nossa aranhinha, em suas distraiçoeiras funções.

Para a mãe-aranha aquilo não passava de mau senso. Para quê tanto labor se depois não se dava a indevida aplicação? Mas a jovem aranhiça não fazia ouvidos. E alfaiatava, alfinetava, cegava os nós. Tecia e retecia o fio, entrelaçava e reentrelaçava mais e mais teia. Sem nunca fazer morada em nenhuma. Recusava a utilitária vocação da sua espécie.

- Não faço teias por instinto.

- Então, faz por quê?

- Faço por arte (COUTO, 2009a, p. 73-75).

Uma pesquisa não tem início e nem fim, ainda que supostamente pensemos numa origem primeira do problema da mesma. Falo de um relato que afirmou o encontro que deu a pensar, um dar a pensar que deu fôlego e velocidade aos "inícios", pelo "meio" dela: a leitura do conto a Infinita fiadeira, de Mia Couto - uma aranha que tece por prazer de tecer, por arte, modo-existência de vida, improdutivos afazeres, sem finalidade última em seu fazer e no produto-teia - fez-me voltar a escritos pessoais, guardados virtualmente num blog, nomeado baú de bordados. Fora uma escrita em que passeei pela lembrança de bordar na infância, um fazer latente que sempre guardava a potência de voltar a ele. Bordar, quando pequena, era um modo de estar junto de minha mãe, no pouco tempo que tínhamos juntas, pois morávamos em cidades separadas. O baú transmutou-se em um porta maquiagem, na penteadeira madeira-clara do quarto. Voltei ao blog, pousei meu olhar sob o baú da penteadeira: Por que não voltar a compor 'improdutivos afazeres' numa pesquisa? Improdutivos afazeres vibrados por linguagens inúteis (e vice-versa) que então iriam compor os dias, numa pesquisa em educação?

Fui por aí. Entre ler, escrever e bordar, passou a ser fôlego na vida, 'inutilidades' que esgotavam "uma tarefa que traz em si sua própria felicidade" (BARTHES, 1970, p. 17). Coloquei-me, então, a estudar um pouco a biologia das aranhiças. Busquei em livros guardados da graduação, passei a observá-las um pouco mais, trouxe um tempo da faculdade em Ciências Biológicas em que estudei sobre comportamento animal, mais particularmente a observação alimentar de uma aranha caranguejeira em cativeiro.

Passei a buscá-las pelos lugares que frequentava, deixando que habitassem um pouco mais meu território. Fui me instalando, sempre que possível, em um modo de estabelecer contatos com seus territórios, atenta aos seus sinais. Tornei-me, por vezes, caçadora das mesmas: tomava uma máquina fotográfica ou um caderno de notas e resolvia, quando sentia necessidade desses elos, permanecer observando aquelas que me permitiam ser vistas (com exceção dos encontros fortuitos, quando então, já habitando um pouco mais os espaços, algumas aranhas apareciam sobre alguns objetos 
da casa).

Entre autores e textos filosóficos, científicos e literários, fui construindo um modo de procurar experimentar e pensar escritas e leituras, culminando na criação da palavra/verbo Fiandar. Fiandeiras ou Fieiras são denominadas os apêndices nos abdomens de alguns aracnídeos e outros insetos que produzem o que conhecemos pelos fios de seda, e que decorre a produção das chamadas teias. Fiar uma grafia, fiandografia, desejo de fiandar, escrever os fios, fios que escrevem. Das fiandeiras das aranhas, um verbo não catalogado é criado para movimentar e operar a escrita e a leitura na pesquisa: Fiandar.

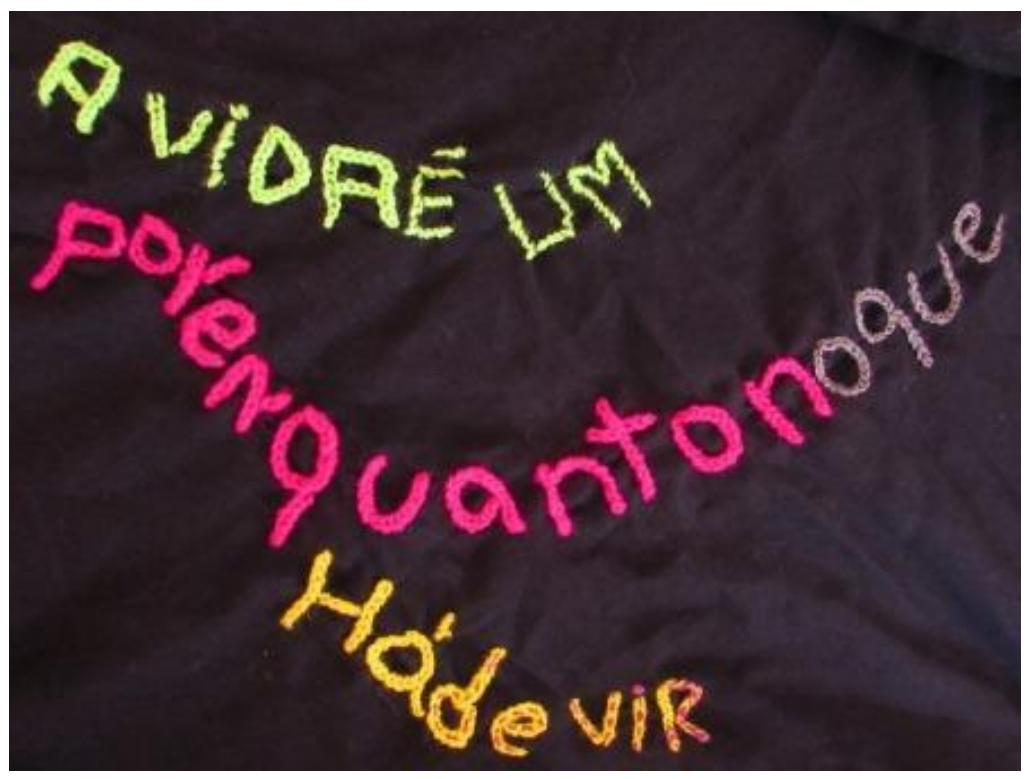

Figura 01 - Materialidade da pesquisa (arquivo pessoal)

Existe uma função muito específica da seda de algumas aranhas, que funciona como linha de reboque, em algumas aranhas que apresentam um modo de vida errante: elas produzem continuamente uma linha de seda seca atrás delas, à medida que vagueiam. A linha de reboque age como uma linha de segurança, visão comum é de uma aranha suspensa no ar, pendurada após ser repelida de algum objeto, que resulta da contínua retenção de sua linha de reboque.

Errantes, ou ditas também como caçadoras, perderam o hábito de construção de teias, constituindo as espécies que têm tipicamente pernas mais pesadas que as construtoras de teias e que vagueiam capturando insetos que acabam encontrando, ao acaso, ou utilizando uma estratégia de tocaia: "a presa é detectada por estímulos visuais e táteis e, em algumas famílias [...], os olhos são bastante desenvolvidos e tem uma importância primária na captura da presa" (RUPPERT; BARNES, 1996, p. 622). São as errantes que

Revista Digital do LAV - Santa Maria - vol. 9, n. 2, p. 7 - 27. - mai./ago. 2016 ISSN 1983 - 7348 http://dx.doi.org/10.5902/1983734823503 
principalmente produzem a linha de reboque, algumas a usando para amarrar sua presa quando é capturada, correndo ao redor dela rapidamente.

Procurando conjugar com esse animal, fui estabelecendo essas zonas de contágio, conjugando com aranhiças errantes, entre linhas de reboque, ou de aranhas que tecem suas teias, de visão pouco aguçada, sensíveis a vibrações e estímulos na teia.

Deleuze faz menção à teia da aranha em alguns de seus escritos: em Proust e os Signos e, com Guattari, em o que é filosofia?. No primeiro, estabelece a aranha como um animal corpo sem órgãos, que nada vê, nada percebe, nada se lembra. Animal movimentado por vibrações, leves, nas extremidades de sua teia, e que se propagam até seu corpo através de ondas e que, então, a faz saltar: "sem olhos, sem nariz, sem boca, a aranha responde unicamente aos signos e é atingida pelo menor signo que atravessa seu corpo como uma onda e a faz pular sobre a presa" (DELEUZE, 2006, p. 173). Equipara a mesma operação à obra de Proust, a Recherche ${ }^{2}$, ela mesma construída como uma teia, sendo o narrador-aranha movimentado pelos signos, onde teia e aranha tornam-se uma mesma máquina

o narrador pode ser dotado de uma extrema sensibilidade, de uma prodigiosa memória: ele não possui órgãos no sentido em que é privado de todo uso voluntário e organizado de suas faculdades. Em contrapartida, uma faculdade se exerce nele quando é coagida e forçada a fazê-lo; e o órgão correspondente vem situar-se nele, mas como um esboço intensivo despertado pelas ondas que the provocam o uso involuntário (DELEUZE, 2006, p. 172-173).

Esse corpo-teia-aranha referente ao narrador da Recherche é esse corpo-teia-aranha que é simultaneamente ativado e que funciona, produz, sob determinadas configurações e agenciamentos. A Recherche-teia é tecida por cada fio que é movimentado por determinados signos, que então lançam o narrador a construir outras linhas, linhas de fuga.

Nos estudos que realizava, procurando relações da aranha e da teia na perspectiva do pensamento da diferença, além de Deleuze e Guattari, utilizei-me brevemente de Jacob von Uexküll (1982), biólogo estonio-alemão muito utilizado pelos autores franceses em livros como Mil Platôs (1997), O que é Filosofia? (1992) e Espinosa: Filosofia Prática, de Deleuze (2002). Uexküll criou a teoria da composição musical da Natureza, a partir da noção de contraponto na composição de uma música, que parte do princípio de que são

\footnotetext{
${ }^{2}$ A la recherche du temps perdu (Em busca do tempo perdido): Deleuze defende que a obra é a própria busca de Proust, a Recherche, por alguma coisa, uma verdade, o que propriamente faz mover sua escrita. Busca que não se dá por um esforço de recordar e explorar a memória em busca desse algo, de escarafunchar lembranças, mas de construir o relato de um aprendizado pelos signos, essência de uma realidade escondida no inconsciente, produzida ao longo de sua vida. Ainda que a memória intervenha como um meio dessa busca, essa memória "só intervém como o meio de um aprendizado que a ultrapassa tanto para seus objetivos quanto por seus princípios. A Recherche é voltada para o futuro e não para o passado" (DELEUZE, 2006, p. 4).
} 
necessários, pelo menos, dois sons para formar uma harmonia.

Na composição de um dueto, as duas partes que se devem fundir numa harmonia são compostas nota por nota, ponto por ponto, uma para a outra. Nisso se baseia a teoria do contraponto, na música. Em todos os exemplos extraídos da Natureza temos, igualmente, de procurar dois fatores que, juntos, constituam uma unidade. Portanto, partimos sempre de um sujeito, situado no seu mundo-próprio e examinamos as suas relações harmônicas com os objetos particulares que, como objetos significantes, convergem no sujeito (UEXKÜLL, 1982, p. 181).

E como seria uma composição musical, a partir de uma 'partitura' da Natureza, e suas relações de contrapontos? Uexküll, de uma forma quase literária, traduz o que para ele já era afirmado como familiar nas suas leituras das partituras da Natureza:

O ramo de flores que a rapariga ofereceu ao namorado era agora usado por este como adorno e o pedúnculo da flor veio assim a entrar num dueto de amor. A formiga que utilizava o pedúnculo como passagem, corria ao longo dele, até ao ovário da flor e aí mungia as suas 'vacas leiteiras' - os pulgões. Quanto à vaca, essa transformava, finalmente, em leite o pasto de que o pedúnculo fazia parte. A larva da aphrophora crescia no seu abrigo, feito do suco que o pedúnculo lhe tinha fornecido e em breve enchia o prado com o seu doce canto de amor. Outros mundos-próprios se vieram juntar a estes. As abelhas, que estavam associadas, em contrapronto, com o aroma, a cor e a forma das flores, acorriam a elas e, depois de se terem saciado de néctar, comunicavam às companheiras a nova fonte descoberta, por meio de danças impressionantes, [...]. Na verdade, a cor das flores não é, para as abelhas, a mesma que é para nós; serve-lhes, no entanto, de certa característica, pois a flor e a abelha estão compostas uma para a outra em contraponto (UEXKÜLL, 1982, p. 198-199).

Diferentes significados possíveis de um mesmo objeto - talo da flor - para diferentes mundos próprios. Uexküll traz a ideia que a Natureza é completamente livre na escolha dos animais que pretende ligar em contraponto, tal como ao compositor de uma sinfonia não são postos limites na escolha de instrumentos. Aplica a comparação musical ao campo biológico, extendendo o conceito de som, do simples som audível, a um 'tom' ou 'teor' significante dos objetos que aparecem como portadores de significado no mundo próprio de cada ente. Em lugar da harmonia, na partitura musical, "intervém o significado, na partitura da Natureza, que serve de elo de ligação, ou melhor, de ponte, para ligar dois fatores naturais" (UEXKÜLL, 1982, p. 202).

E o que me interessara sobre a composição de partituras para a relação aranha-mosca? A aranha, neste caso, constrói sua teia sem ter encontrado qualquer mosca. Ela 
apresenta o desenho de um modelo de mosca que não existe em parte nenhuma. O que Uexküll explica é que existe uma partitura inicial para a mosca, tal como existe uma partitura inicial para aranha. "Ora eu afirmo que a partitura inicial da mosca (que também podemos designar por protótipo) atua na partitura inicial da aranha, de modo que a teia tecida por esta resulta numa teia 'própria para capturar moscas'" (UEXKÜLL, 1982, p. 166).

Há aí uma relação de contraponto na relação aranha-mosca. A aranha apresenta em seu aparato codificatório um 'motivo' de mosca, ou seja, diríamos que a aranha tem uma 'mosca na cabeça', onde a teia de aranha implica no código desse animal sequências do próprio código da mosca (DELEUZE; GUATTARI, 1997), como um impulso interno e funções que mobilizam a aranha em seu território. É como dizer que há qualquer coisa de mosca, na aranha.

Concepção de Natureza "melódica, polifônica, contrapontual", em que a teia de uma aranha contém "um retrato muito sutil da mosca" que lhe serve de contraponto. Certa arquitetura cega que estabelece uma relação com posturas, movimentos, traços da mosca, "interceptando o trajeto" de um animal sem território, "formando junções interespecíficas" com ela (DELEUZE; GUATTARI, 1992, p. 239). Um jogo de intermodulações, jogo entre espécies, de transitar por territórios e se transformar nesse jogo: "Essas relações de contraponto juntam planos, formam compostos de sensações, blocos, e determinam devires" (DELEUZE; GUATTARI, 1992, p. 239).

Devir-mosca da aranha. Os mundos perceptivos de mosca e aranha nos servem para pensar a percepção entre mundos heterogêneos. Esses mundos perceptivos não se comunicam em absoluto, mas estão tão perfeitamente em acordo, como uma partitura musical. Ainda que a aranha não possa perceber objetivamente o espaço de uma mosca, ela pode entrar em relação em um ponto de contato com esta, através de sua marca territorial, a teia (CANGI, 2008).

Del mismo modo entre garrapata y el mamífero. La Naturaleza revela una ceguera entre especies y sin embargo, acentúa una composición por afección que incrementa la potencia de funcionamiento entre éstas. De este modo, se es afectado por el mundo en función de lo que se es capaz y se percibe en función de las acciones que se pueden realizar (CANGI, 2008, p. 93-94).

Tratava-se, assim, de ir fazendo pegadas numa pesquisa, nas tentativas de encontrar o outro ao nível molecular, por um contágio vibratório, na contiguidade de uma relação entre heterogêneos. Esse contágio implica uma proporção de movimento e de repouso, na zona de proximidade que se estabelece entre dois ao experimentar uma maneira de ser, pensar e sentir, sem deixar de ser o que se é. "O rato que se torna pensamento no 
homem, e o homem que se torna rato, animal que mostra os dentes e agoniza" (DELEUZE; GUATTARI, 1997, p. 44). Experimentações do grau de potência de um animal, suas velocidades e lentidões, "un diagrama de movimientos y relaciones más que un conjunto de caracteres" (CANGI, 2008, p. 97).

Em modos de ler e escrever, experimentar construir relações não dadas, inventar relações com interlocutores diversos, "as massas, o leitor, os Estados, o Oceano..." (DELEUZE, 1997, p. 70), ao modo como faz a literatura de Walt Whitman. Contrapontos, algo que sempre renova, inventa relações, estabelece a Natureza mesma - e um texto não como forma, mas como constantes processos de co-relações: "a Natureza é inseparável de todos os processos de comensalidade, convivialidade, que não são dados preexistentes, porém se elaboram entre viventes heterogêneos de modo a criar um tecido de relações moventes que fazem com que a melodia de uma parte intervenha como motivo na melodia de uma outra (a abelha e a flor)" (DELEUZE, 1997, p. 71).

Ter certa liberdade de atentar e intervir nessas construções e de poder experimentar relações de contraponto com outros seres, sem saber como isso se dá. Sempre ao modo de fazer uma alusão a esses campos conceituais e teóricos, não para explicá-los tampouco determiná-los, mas para experimentá-los enquanto um modo de produzir uma pesquisa, de 'juntar muitas coisas' para, quem sabe, pensar leituras, escritas, educação.

Não trouxe imagens da aranha para que se fizesse como uma aranha. Se agitei e coloquei 'as coisas todas juntas', pinçando em textos de zoologia e filosóficos e literários, talvez porque em meio a eles, entre uns e outros, é que fui estabelecendo relações de contraponto, num objeto de poética, de pensamento. Esses seres abjetos de medo e repulsa desorganizaram os tecidos usados de uma vida e, fizeram costurar, sob condições incertas, outras instâncias do pensar.

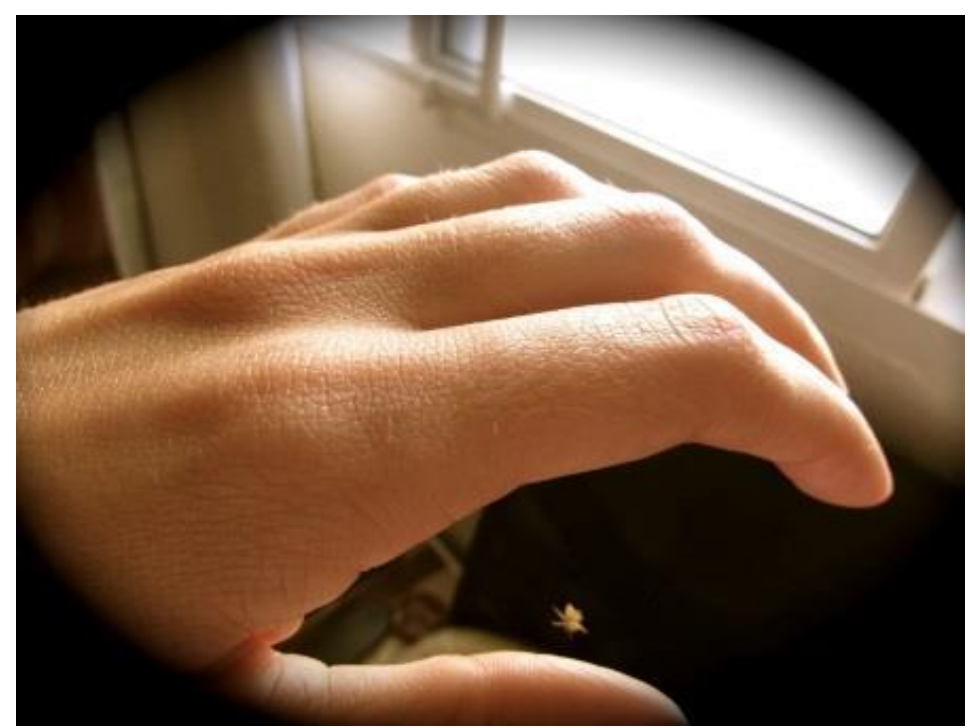

Figura 02 - Materialidade da pesquisa (arquivo pessoal)

Revista Digital do LAV - Santa Maria - vol. 9, n. 2, p. 7 - 27. - mai./ago. 2016 ISSN 1983 - 7348 http://dx.doi.org/10.5902/1983734823503 


\section{E sobre o tecido (e 'bordar palavras tortas')?}

O que pode esse tecido e esse bordado? Um espaço que se criava, uma relação de espaço e de tempo que busquei criar na pesquisa para que algo se passasse. Perceber que esse momento de bordar era de, passivamente, esperar que algo se passasse na relação com as linhas, com as cores, com o tipo de ponto que escolhia, que algo fizesse vibrar a teia enquanto se fianda. Quando criava esses tempos e espaços para bordar, o desejo era de entrar em relação, agenciar com esse tecido, com as lãs, com o que penso, e escrevo (escrevendo em mim o texto que outrora tenha lido, com as coisas que disse, com a conversa que se teve em espaços diversos, e que acabavam se tornando escrita). Bordei e permaneço bordando palavras tortas. Bordo pra ver se as desentorto, mas acabo por transformar o corpo de palavras em texto e em bordado, entortando-as mais. É assim... escrita torta, rota. Bordar sem traço prévio de como pegaria um lápis e as traçaria, deixa que o corpo tenha que compor com a textura do tecido, o volume de pano que é preciso deter na outra mão e puxar a linha para conseguir fiar com a agulha.

Fiandar palavras tortas é também traçar possíveis na vizinhança com palavras-outras, textos, bichos, pessoas. Borda-se para ocupar outros lugares do corpo-pensamento, entortar palavras para entortar-se, (de)formatar-se, de-formar-se (para, por vezes, deixar de ser aquilo que vem sendo, desaprender, desinvestir nas identidades maiores). Vazar as formas e as fôrmas, porque somos rebaixados demais, formados demais.

Desabitar e criar ritmos de outras escritas, enunciados, compor com. Conjugar com as simpatias, falar com e escrever com pessoas, personagens, corpos físicos, biológicos, verbais. "É isso agenciar: estar no meio, sobre a linha de encontro de um mundo interior e de um mundo exterior" (DELEUZE; PARNET, 1998, p. 65), tornando-se outra coisa, estar em cada coisa, desaparecendo com o mundo.

O fiandar me põe num por vir ininterrupto e imprevisível, ao gosto de não se prever a forma que esse tecido que resistiu e insistiu no tempo, tomará. Experimentar um tecer de linhas, que procurou escapar de um comunicar: o processo de escrita é a própria experimentação, permeada por um fazer corpo dessas linhas de escrita, linhas da vida. Um fiandar que persiste em meio à docência, como resistir nos espaços e discursos que nos adoecem. Uma cura, um fiandar infinito.

Ir compondo, com todos esses elementos, uma melodia, produzindo outros agenciamentos com eles. Então, o bordado foi parte constitutiva desse outro corpo do trabalho, também movimentando a escrita e o pensar a partir desses encontros que se tinha com tecidos, lãs, pontos, cores. Foi um modo de me colocar nessa pesquisa, modo que se cria nesses intervalos, esses espaços, esses vazios, para pensar sobre leituras e escritas, pensar no que acontece agora, aqui, na vida, no entorno.

Procurei operar um 'estar à espreita' (DELEUZE; PARNET, 1998), do que podia passar

Revista Digital do LAV - Santa Maria - vol. 9, n. 2, p. 7 - 27. - mai./ago. 2016 ISSN 1983 - 7348 http://dx.doi.org/10.5902/1983734823503 
enquanto bordava, e interessante perceber que, aí, coisas se davam (coisas que até então não existiam, passaram a existir), se pensaram e se produziam e se realizavam, nessa relação com o tecido e linhas, com esse corpo-pensamento que aí se instou e produziu.

Fiandei com linhas produzidas na leitura de alguns escritos de Mia Couto, com as crianças ou figura-mulher de algumas obras do autor, que não intentaram em escrever sobre uma infância, mulher, animal, coisas e seres, mas de "contar a experiência" do encontro, ou do "reencontro" com uma mulher, um animal, uma infância, com qualquer coisa (LARROSA, 2014, p. 152) a partir e com a leitura desse autor.

Contudo, esta pesquisa, na operação de uma Fiandografia, desejou deglutir autores, essas "pedras da sorte" que nos servem como "pretextos para a experimentação" (LARROSA, 2005, p. 77). Apresentou, assim, blocos de escrita, tratando do encontro que tive, "o devir, o roubo, as núpcias" (DELEUZE; PARNET, 1998, p. 17) que estabeleci com ideias, seres, acontecimentos, e disparam a escrever. Estes escritos estavam, muitas vezes, em modos de soarem como opiniões, ainda que se desejasse fugir disso. Denominei-os Saltos e Re-saltos, em alusão aos saltos de uma aranha, e fazem parte desses escritos esparsos, tecidos junto às leituras do doutorado ou mesmo de outros escritos, conversas, escutas.

Os Saltos fizeram alusão às linhas de reboque das aranhas, linhas-engatadas-arrastadas, fixadas sem um plano ou fluxo ordenado, produtoras de vazios e espaçamentos no tempo. São escritos e imagens que foram espaçando a pesquisa, em meio à leitura de livros literários e/ou filosóficos, não havendo uma necessária articulação entre estas linguagens.

Fiandar-grafias, junto às costuras de textos, às imagens que foram cruzando e ajudando a potencializar esse tear de fios, traz um pouco dessa artesanagem da vida, daquilo que nos torna tudo ao mesmo tempo em educação. Fiandar trata um pouco disso, e de outras instâncias que ainda (e sempre) não se atingem.

Revista Digital do LAV - Santa Maria - vol. 9, n. 2, p. 7 - 27. - mai./ago. 2016 ISSN 1983 - 7348 http://dx.doi.org/10.5902/1983734823503 


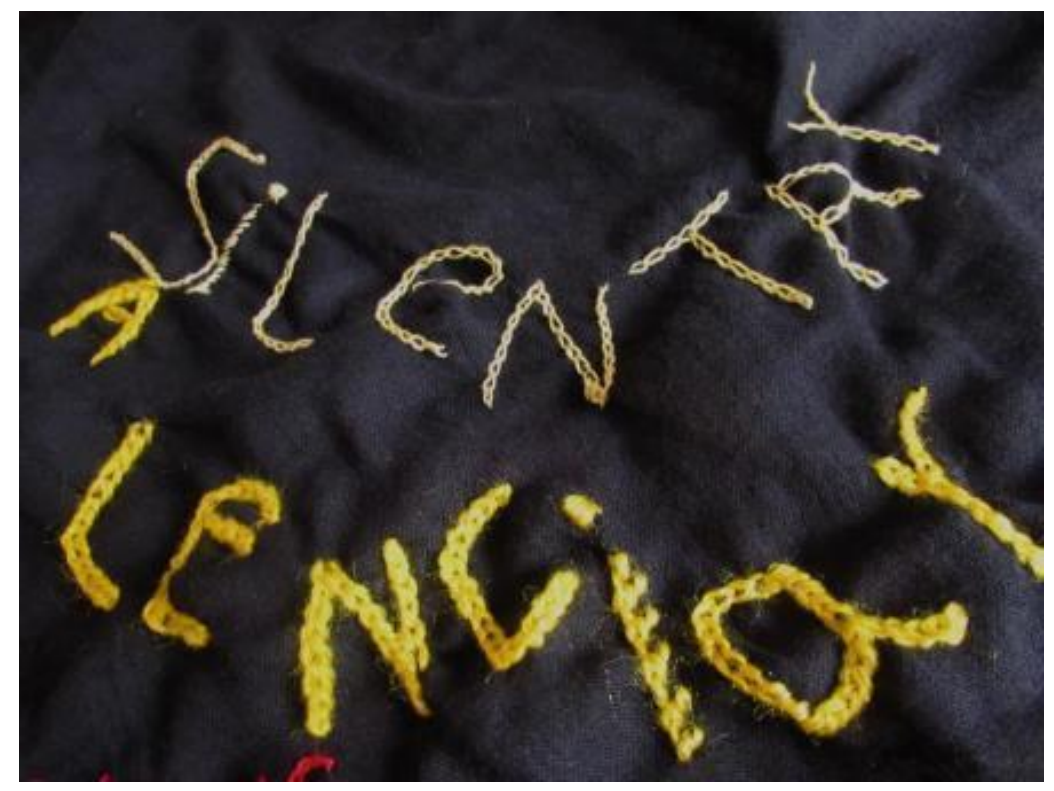

Figura 03 - Materialidade da pesquisa (arquivo pessoal)

\section{Das Fiandagens: afinar Silêncios ${ }^{3}$}

A família, a escola, os outros, todos elegem em nós uma centelha promissora, um território em que poderemos brilhar. Uns nasceram para cantar, outros para dançar, outros nasceram simplesmente para serem outros. Eu nasci para estar calado. Minha única vocação é o silêncio. Foi meu pai que me explicou: tenho inclinação para não falar, um talento para apurar silêncios. Escrevo bem, silêncios, no plural. Sim, porque não há um único silêncio. E todo o silêncio é música em estado de gravidez.

Quando me viam, parado e recatado, no meu invisível recanto, eu não estava pasmado. Estava desempenhado, de alma e corpo ocupados: tecia os delicados fios com que se fabrica a quietude. Eu era um afinador de silêncios.

- Venha, meu filho, venha ajudar-me a ficar calado.

Ao fim do dia, o velho se recostava na cadeira da varanda. E era assim todas as noites: me sentava a seus pés, olhando as estrelas no alto do escuro. Meu pai fechava os olhos, a cabeça meneando para cá e para lá, como se um compasso guiasse aquele sossego. Depois, ele inspirava fundo e dizia:

-Este é o silêncio mais bonito que escutei até hoje. Lhe agradeço Mwanito.

Ficar devidamente calado requer anos de prática. Em mim, era um dom natural, herança de algum antepassado. Talvez fosse legado de minha mãe, Dona Dordalma, quem podia ter certeza? De tão calada, ela deixara de existir e nem se notara que já não vivia

\footnotetext{
3 Há alguns subcapítulos na Tese que pertencem ao Capítulo Das Fiandagens e que tratam das articulações de escritos da autora com as vozes de alguns autores. Neste caso, o subcapítulo trazido para mostrar um pouco dessas misturas de vozes foi o Afinar Silêncios, no qual fiando com os escritores Couto (2009b) e Ferraz (2005).
} 
entre nós, os vigentes viventes.

- Você sabe, filho: há a calmaria dos cemitérios. Mas o sossego desta varanda é diferente.

Meu pai. A voz dele era tão discreta que parecia apenas uma outra variedade de silêncio. Tossicava e a tosse rouca dele, essa, era uma oculta fala, sem palavras nem gramática (COUTO, 2009b, p. 13-14).

Mwanito-silêncio. Silêncios, no plural. Silêncio de uma vida nunca vivida, de uma mãe nunca conhecida, de uma sombra inexistente. Silêncios de inocência infante. De um nada poder, ainda que seus dias resistam ao árido dos pulmões de Jesusalém, terra de nada(r) em ninguém. Mwanito-abraço, ímpeto, desejo. Devir-Mwanito.

Palavras que rumorejam certa delicadeza, resignada a permanecer enclausurada nas poucas coisas que são ditas, na vida que resiste em não adoecer a afecção. Aspereza de um mundo que se sabe falecido, mas que ainda guarda a insistência a resistir, em gritar o fio de vida. Vidas informes que permeiam o nada que lhes resta, em suas fomes de comida e de mundo, expressam o impessoal, neutro, e carregado em potência. E junto ao texto, enquanto se lê e se escreve, uma escuta: guardar sons, cores, gestos; soltar juízos, palavras, movimentos, traços, rostos, espasmos, deixar que se façam no ar. Como afinar um silêncio? Como afinar as palavras a ponto de torná-las silenciosas? Silêncio que não deseja falar, mas que ainda assim fala. Que sai do que esperamos, que não nos corresponde quando não nos devolve respostas; quando achegados e desconhecidos silenciam diante de nossa verborragia, de nossa ânsia de fala. Esse silêncio que nos força a pensar: "Por que não falam? Por que tanto silêncio?" Como produzir silêncios em meio aos lugares de docência e de vida? Como calar a moral, um pensamento que diz o que deve ser? Afinar silêncios talvez seja demorar-se em lugares distantes de nosso esquema pronto de pensamento; aproxima-nos de algo que é desconhecido, não representável. Campo mais aberto, sensível, grávido de sons, de invenções sobre nós mesmos.

Não é fácil de súbito calar o altifalante que me ligaram à garganta, de encobrir as lentes que nos meus olhos esconderam, de rebentar as membranas que lá no fundo dos meus ouvidos vibram. É isso que quero tentar. As palavras saltam em mim, dentro de mim, querem irromper de todos meus orifícios e cobrir o espaço. As conquistas verbais, todas as pequenas mordidelas de formiga das palavras e dos adjectivos. Depois de ter aprendido a falar, ao indivíduo o que é que falta? Falta aprender a calar-se; é isso (LE CLÉZIO, 1989, p. 33).

Não é fácil suspender esse texto. A maior parte dele, enquanto se lê, é uma paralisia inquieta, violência do incomum, uma espera de outras palavras, que não aquelas óbvias

Revista Digital do LAV - Santa Maria - vol. 9, n. 2, p. 7 - 27. - mai./ago. 2016 ISSN 1983 - 7348 http://dx.doi.org/10.5902/1983734823503 
da falta de som que grita palavras na cabeça. Olhar para os lados e fugir do livro, para encontrar essa ética de, depois de ter aprendido a se dar o direito de falar e escrever, também aprender a calar; "silêncio índio, que não é mutismo, que não é contemplação inactiva. Silêncio que é interpretação possível de linguagens várias, escuta de variadas vozes. Quero procurar aprendê-lo. Vai ser preciso para isso eliminar em mim palavras, proceder à eliminação" (LE CLÉZIO, 1989, p. 33).

Como se acessa esse lugar que parece ser o espaço de um salto, onde desabilitamos a ânsia de sobreposição ao outro, o controle dos acontecimentos e pessoas, de nossos afectos? Como aprender a possibilidade de um Salto como silêncio? Que acessa um espaço de liberdade do qual nos libertamos de um "ser-sujeito" e das sustentações de identidades fixas? Não temos nem permanecemos na região de um Salto, mas podemos entrar em relação com ele, vislumbrar um silêncio-espaço onde percebemo-nos como não fundados, carentes de qualquer fundo ou qualquer fundamento, como desprovidos de qualquer razão ou de qualquer princípio que pudesse dar conta de nós (LARROSA, 2005).

Como habitar nesse silêncio, existir nessa outra linguagem, "que está para além das acusações e das responsabilidades" (LE CLÉZIO, 1989, p. 31)? O silêncio sentido em educação é o do afogamento do som, da dor do mutismo, compressão da garganta, sufocamento, inchaço das cordas vocais dos sons e ruídos e gritos que não devem sair. Os gestos assustam, as outras linguagens são solicitadas, mas apenas na 'hora certa', com sua devida utilidade. Afogamo-nos com nossas próprias palavras não ditas.

Em outra região, insiste a cacofonia, excesso das palavras, dos gritos, dos sons de cruzamentos de trânsitos, slogans por toda parte, cimentações de palavras que não cessam de se fazerem na mente, mesmo que forcemos a inutilidade do nosso ego. Querem sempre adivinhar palavras em nós, colocar palavras em nós e, então, colocamos palavras em nós. "Há uma tal quantidade de palavras a multiplicar a sua casta, a nascer a cada segundo, palavras terríveis e belas palavras, palavras. Aquele que não fala vai talvez morrer. Aquele que se recusa a falar, que cerra os dentes e resiste à vaga das palavras, vão talvez matá-lo, apagá-lo da face da terra" (LE CLÉZIO, 1989, p. 32).

Salto como possibilidade de silêncio. O silêncio como possibilidade de saltar. Possibilidades que não compõe com os que se retiram de seus lugares de falantes, do alto de seu saber e autoridade, para ocupar o lugar do 'ouvinte ideal', numa falsa modéstia de que, efetivamente, o que importa é o que ele, de fato, sabe. O salto como possibilidade de silêncio, e silêncio como possibilidade de ocupar o lugar de um salto, é esse instante em que se percebe - e, quem sabe, aprende-se - que já não há mais muito o que dizer. "Como se, de tanto falar e falar, houvesse um momento em que a linguagem minasse um território até ali ignorado: o da ligeireza habitual das palavras, a 
confiança cega e habitual no sistema, a mesquinhez dos sentidos, a crença de que é possível falar de qualquer coisa, a dissolução do mito em que o mundo se representa como questão de alguns nomes, alguns poucos adjetivos" (SKLIAR, 2014, p. 27).

Que quando ele nada disser com a boca, "talvez outra coisa diga com as mãos, com as costas, com as narinas" (LE CLÉZIO, 1989, p. 33), que o faça decantar a ânsia pela análise e pelos interrogatórios. Uma ausência de fala que vaze também por uma ausência de escrita, que é possibilidade de outras escritas se fazerem.

A inabilidade de escrever a sensação de um silêncio-salto talvez nos torne atentos a ele, e que também não há outro modo de traçar essas linhas de salto-silêncios a não ser experimentando. Talvez afinando uma escuta que não significa mais privilegiar um som. Ou, quem sabe, privilegiar pequenos sons, algo que nos coloque ouvidos, olhos, o corpo no mundo... Que nos faça saltar: "diante do salto, o olho tem de se mexer, o ouvido precisa se readaptar, o corpo se recurvar e tomar nova forma; a mão tropeça em uma ranhura e ganha nova aderência, o pensamento muda de lugar. Seja no ver, no ouvir, no rastejar com o corpo, no roçar a mão, existe aí uma experiência de um corpo sendo arrastado para fora de um lugar: o hábito. A exigência de tomar uma nova posição, nova forma..." (FERRAZ, 2005, p. 85).

Talvez um caminhar solo, uma gota de chuva inesperada sob nosso nariz, o coaxar de sapos, um som desconhecido que saia de nossa boca, os pés que respondem ao gelado da água, o som da chuva de folhas de um céu verde, os ruídos que saem de nosso corpo, um lugar que fomos lançados numa leitura e que nos perdemos por um tempo. Talvez o silêncio de que falem seja o da criança que joga, um som que ela cantarola enquanto brinca ou se esconde. O silêncio do idoso que é um riso, um riso que se engatinha ao visitar um modo de ser da criança. Saltos-silêncios: atiçar pontos e pinçar linhas de cumplicidade entre um pequeno e uma velha que persistiam em se encontrar: é preciso experimentar.

Ria, ria, ria-se todo. Tinha algo ali que nem o passarinho explicaria. O neném olhava pra aquele ser enrugado na sua frente, que se enrugava quanto mais se ria, e tremia o corpinho por não saber o que fazer com aquilo. O miúdo não tinha nojo, nem medo, nem nada dessas coisas que adulto sente por velhos. Essa palavra idoso é como se escondesse de fato o que ela era. Era velha, e velho, pro mundo, não é bonito. Não toma banho porque esquece. Mija nas calças porque seu corpo vai mais que sua consciência pode fazer. Deixa de dizer sim ou não por quem quer que seja. Segue o que vibra. Mas o miúdo, o miúdo não a julgava, não temia, nem rejeitava. Quando ele a vê, ele ri, como sempre riu. A velha que deixara de pegar o miúdo no colo. Miúdo pesa, engordeceu rápido de tanto peito. Mas ela se apresenta toda a sua frente, e fica tão bonita assim, mulher, falando a linguagem do miúdo que é riso.

Revista Digital do LAV - Santa Maria - vol. 9, n. 2, p. 7 - 27. - mai./ago. 2016 ISSN 1983 - 7348 http://dx.doi.org/10.5902/1983734823503 
Um ria: pá, o outro ria de novo e vai além. Miúdo e Graúda, criança e velho: num o riso da vida que ainda não Ihe incumbiu morais e bons costumes, em outro, o riso do corpo cansado do que fez a vida toda, que foi chorar, criar filho e cuidar do seu velho.

Pequenez do momento explica uma linguagem: riso. Riso de aproximar, afrouxar, amassar, cuidar, alimentar, acarinhar, acalmar. Criança não se engana. Tem um risolinguagem, sem palavras, sem explicações, objetivos, mas um riso de sentir rio, de deixar que a vida leve, lave, abrande. Ria-se. A linguagem que o pequeno de meses já entende que funciona e que chama. Riso sem preconceito, que desinventa e desinveste essa mania boba de se dizer adulto. Adulto que não ri. Riso-rio adulteceu: ficou escuro, perdeu volume. Quer-se o riso cúmplice, amigo, guardião, mas sem peso, posse, possuídos.

- Riso-livre, então?

- É. Esse de quando estamos embriagados, de sorrir o nada, a dança, o cheiro. De rir de si mesmo, e se perder. Rir que se perde em ser rio, sabe?

Sei não. Acho que perdi pelo caminho...

- Perdeu, não. Deve de tá aí escondido na ruga trêmula, no sonho contido, no choro preso. Porque rir é chorar também.

Chorar e rir são parecidos porque os dois quando começam, se vão. Vão e voam, sem início e nem fim. Chorar e rir é que nem festa de cegos: quando começa, ninguém sabe de onde vem, nem por quê.

- Hum... E faço como pra ser cego?

- Finge que conhece. Faz que esqueceu.

- Esqueceu de quê?

- Que esqueceu que conhece tudo na vida. Apaga o mundo e o homem. Continua sendo criança, miúdo até ficar velho. Ri quando chora e chora quando ri, sem saber onde um e outro termina! Se der, fecha os olhos junto. O mundo, e tu todinho, miúdo, vão mudar de cor (Escritos da observação do encontro entre dois - os 88 anos de um e os 10 meses de outro).

\section{Fiandar: um por enquanto no que há de(vir)}

Fiandar como um modo de produzir escrileituras numa pesquisa. Também um modo de perder identidade e medo, e se tornar presença; que envolveu não somente articular escritos e bordar palavras tortas. Fiandar permanece no processo de escutar, produzir silêncios-saltos, vaguear entre as coisas, ler e escrever sem procurar regras e leis, artesania que se envolve em experimentar conceitos em meio à vida, ainda que o já pensado e o já dito persista em nós. 
Fiandar como uma secreção que se expele: produzir palavras, num tempo de secretar o que consigo posso compor com um texto. Fiandar-parar-calar, suspender julgamentos, ditos e práticas; fiandar que agarra o que está a ponto de ser gesto e palavra, mas que não consegue sê-lo. Que caça os vapores do mundo, não para esquecer quem sou, mas para que possa diferir no que sou. Caçar saídas no agora, entre o que se diz e o que se vê, entre o que não se diz e não se vê. Fiandar como força que dá passagem ao ingovernável em nós.

Escritas e leituras que transitaram pela sensação do que, por vezes, não pode ser nomeado, de uma linguagem insuficiente para conceituar e dar nome às coisas. Então, houve espaçamentos para pausas, fôlegos, ar, saltos, náuseas. Essa escrita que se deu no 'entre' tentou achar saídas, distintas dentro da soberania do registro, da devolução do aprendido, do código a ser avaliado (SKLIAR, 2014), ainda que ela tenha que ser avaliada.

Fiandar consistiu até mesmo em sacudir o lugar comum do leitor (aquele que se espera que seja 'bem formado', 'intelectual' e em 'busca de informação'), para jogar esse leitor a outros territórios. A leitura que de-forma, que desforma, que des-in-forma, que arranca o rosto, que faz, quem sabe, fazer esse leitor entrar num devir-mosca, que passeia pelo amontoado de teias que é o texto. Des-instaurar esse lugar do leitor porque o lugar de autor também foi desinstaurado.

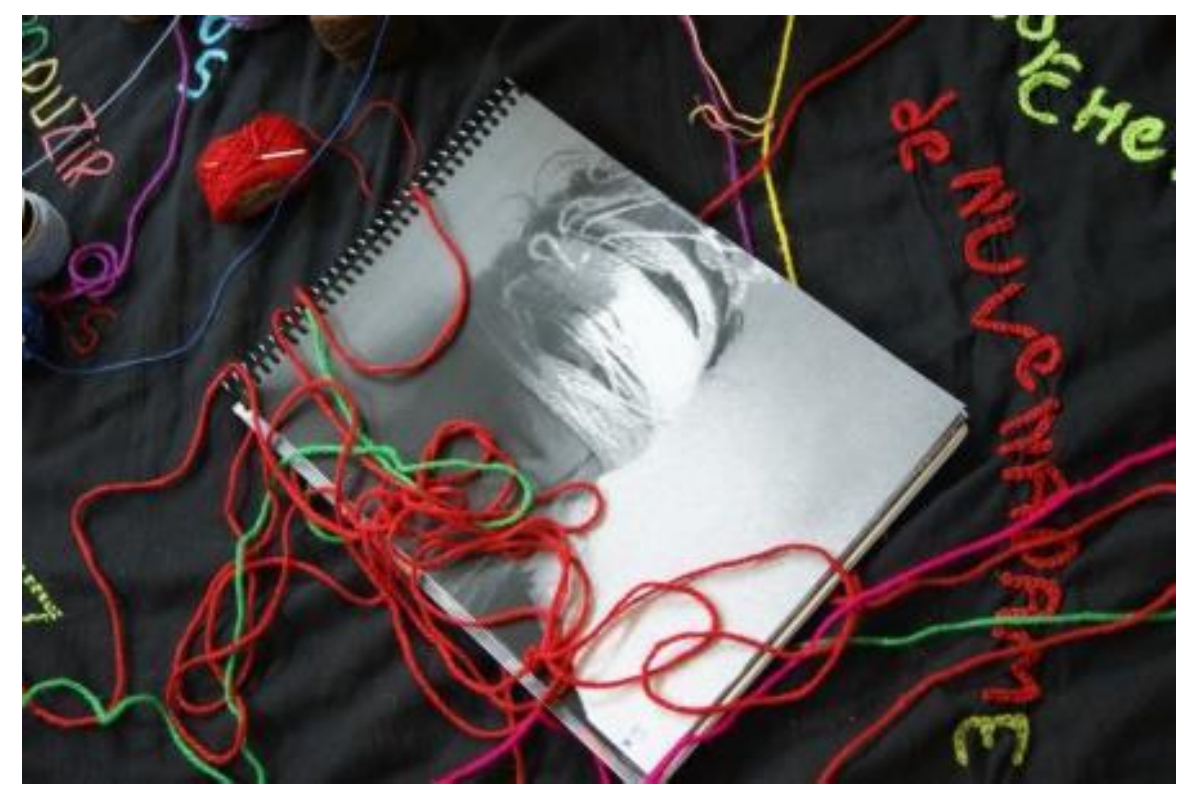

Figura 04 - Materialidade da pesquisa (arquivo pessoal) 
Permiti-me, no percurso dessa pesquisa, desordenar as ideias dadas sobre pesquisa e educação para poder atender ao mundo e dar chance de produzir existências nesse percurso, de aprender com a possibilidade de não ter que se explicar em demasia: "abrir um espaço dentro da norma, para que surja o outro" (SKLIAR, 2014, p. 189). Uma fiandografia procurou funcionar no exercício de deslizar pelas coisas, de "irromper no meio das coisas" (DELEUZE; GUATTARI, 1997, p. 74), para poder escrever, para que pensamento conjugasse com a vida mesma. Coloquei-me exposta ao desarranjar do saber acumulado, do corpo estruturado, do sentir representado, ainda que se usasse de tudo isso para comunicar, atingir uma linguagem inteligível.

Deglutir e deformar autores, acessar regiões de um salto, afinar silêncios; suspender textos e ditos, desabilitar o controle dos acontecimentos, desafogar os pequenos sons do mundo, tomar uma nova forma; vaporizar, traçar, prender, soltar linhas, escrever sem destino e esperar. Relativo a compor maneiras de ler, escrever e viver como um processo de pesquisar; um aprender no encontro com o heterogêneo que trata mais de um desaprender; uma autoformação que desaprende por se de-formar: des-aprendi a escrever por entre teias e afecções de uma aranha, leitura de textos literários, filosóficos e científicos, com uma criança e um velho, com fios, linhas e bordados; des-aprendi com a permissão de escrever, de experimentar corpo e pensamento, com as brigas dos fascistas que moram em mim, com uma mulher passante, com escritos de meu pai, com silêncios e imagens; com personagens da literatura, com uma aula de dança, com um grupo de mulheres, com um tecido negro, com espaços de fala coletiva e de imobilidade na pesquisa, onde, e quando, nada se passa.

Instalo-me, agora, em sobrevoar os fios traçados até aqui: perceber que já se deixou de ser tanta coisa para se tornar tantas outras. Mas esse sobrevoo carrega nos olhos o desejo de construir-se nas performances das asas, a velha dança ordinária dos antigos que nos gritam: há sempre em ti - e fora de ti - o movimento de "deixar o estado de ser uma coisa para voltar ao estado de AINDA não ser uma" (TADEU, 2004, p. 31). Insuportável rio que se entra e que se sai sempre outro, rio que nos faz morrer e nascer em vida.

Apagar bordados e escritos e falas, ainda que não se apaguem. Talvez um movimento que independa de um autor que o faça. O que se alcança e é experimentado se une ao inacessível, a tudo aquilo que não foi, não se fez, pensou, viveu. Diagnosticar devires, experimentar, que é atentar ao que se está fazendo, e o que se está fazendo "não é o que acaba mas menos ainda o que começa" (DELEUZE; GUATTARI, 1992, p. 143).

Por isso, leitura e escrita permanecem penduradas no tempo, em reserva de se tornarem outra coisa nos saltos que fizeram, no silêncio gerado, ou ainda em seus estados de gravidez. Elas desataram nós, instalaram outros mais fortes, produziram linhamentos e 
enroscos e, a todo momento, a paralisia, uma incompleta imobilidade, também se fez. Se fez enquanto buracos no tempo, como uma aranha que observa sem observar, em modo de espera por algo que faça o corpo ser engatilhado à ação: é possível nada passar. Penso que isso também seja aprender, porque a atmosfera da vida consiste em permanecer imóvel num tempo intensivo.

São estas linhas que se enlaçam, misturam-se, e são lançadas, vazadas, interrompidas de um corpo que se pulveriza, que captura e é capturado, em diferentes circunstâncias de pesquisa e docência. Estas descontinuidades que permanecem vibrando a teia e encapsulando quem lê, quem escreve, quem pesquisa, quem vive. Boicotar-se, ser devorada por aquilo que não pega, alcança, mastiga, digere. As palavras que nunca se encontram, sentidos nunca dados, brancos voláteis: as páginas da pesquisa se perderam em serem evidentes, certas, compreendidas. Linha de reboque solta, tensionada na medida que outro salto se faça... saltos ainda não dados.

\section{Referências}

BARTHES, Roland. Crítica e verdade. São Paulo: Perspectiva, 1970.

. O grau zero da escrita: seguido de novos ensaios críticos. Tradução Mario Laranjeira. 2.ed. São Paulo: Martins Fontes, 2004. . O prazer do texto. Tradução J. Guinsburg. 4.ed. São Paulo: Perspectiva, 2008. . O rumor da língua. Tradução Mario Laranjeira. 3. ed. São Paulo: WMF Martins Fontes, 2012.

CANGI, Adrián. Anomalías. Gilbert Simondon, una filosofia de la individuación (posfácio). In: SIMONDON, Gilbert. Dos leciones sobre el animal y el hombre. Buenos Aires: La Cebra, 2008. p. 79-110.

CORAZZA, Sandra Mara. O que se transcria em educação? Porto Alegre: UFRGS, 2013. COUTO, Mia. O fio das missangas: contos. São Paulo: Companhia das Letras, 2009a. . Antes de nascer o mundo. São Paulo: Companhia das Letras, 2009b.

DALMASO, Alice Copetti. Fiandografia: experimentações entre leitura e escrita numa pesquisa em educação. Tese de Doutorado. Universidade Federal de Santa Maria. Centro de Educação. 2016.

DELEUZE, Gilles. Crítica e Clínica. Tradução: Peter Pál Perbart. São Paulo: Ed. 34, 1997. . Espinosa: filosofia prática. São Paulo: Escuta, 2002.

. Lógica do sentido. Tradução Luiz Roberto Salinas Fortes. 4.ed. São Paulo: Perspectiva, 2003.

Proust e os signos. Tradução Antonio Carlos Piquet e Roberto Machado. 2.ed. São Paulo: Forense Universitária, 2006.

. Conversações. Tradução Peter Pál Perbart. 3.ed. São Paulo: Ed. 34, 2013.

Revista Digital do LAV - Santa Maria - vol. 9, n. 2, p. 7 - 27. - mai./ago. 2016 ISSN 1983 - 7348 http://dx.doi.org/10.5902/1983734823503 
DELEUZE, Gilles; GUATTARI, Félix. O que é filosofia. Tradução Bento Prado Jr. e Alberto Alonso Muñoz. Rio de Janeiro: Ed. 34, 1992.

. Mil Platôs: capitalismo e esquizofrenia, v. 1. Tradução Aurélio Guerra Neto e Célia Pinto Costa. São Paulo: Ed.34, 1995.

DELEUZE, Gilles; GUATTARI, Félix. Mil Platôs: capitalismo e esquizofrenia, v. 3. Tradução Aurélio Guerra Neto, Ana Lúcia de Oliveira, Lúcia Cláudia leão e Suely Rolnik. São Paulo: Ed. 34, 1996.

Mil Platôs: capitalismo e esquizofrenia, v. 4. Tradução Suely Rolnik. São Paulo: Ed.34, 1997.

DELEUZE, Gilles; PARNET, Claire. Diálogos. Tradução Eloísa Araújo Ribeiro. São Paulo: Escuta, 1998.

FERRAZ, Silvio. Livro das sonoridades [notas dispersas sobre composição] - um livro de música para não-músicos ou de não-música para músicos. Rio de Janeiro: 7 Letras, 2005. Disponível em: <https://www.academia.edu/7779315/Livro_das_Sonoridades>. Acesso em: 18 dez. 2015.

GODOY, Ana. Conservar docilidades ou experimentar intensidades. In: PREVE, Ana Maria; CORRÊA, Guilherme (Orgs.). Ambientes da ecologia: perspectivas em política e educação. Santa Maria: UFSM, 2007. p. 121-138.

LARROSA, Jorge. Linguagem e educação depois de Babel. Tradução Cynthia Farina. Belo Horizonte: Autêntica, 2004.

LARROSA, Jorge. Nietzsche \& Educação. Tradução Semíramis Gorini da Veiga. 2.ed. Belo Horizonte: Autêntica, 2005.

Pedagogia profana. Tradução Alfredo Veiga-Neto. 5.ed. Belo Horizonte: Autêntica, 2010.

Tremores: escritos sobre experiência. Tradução Cristina Antunes e João Wanderley Geraldi. Belo Horizonte: Autêntica, 2014.

LE CLÉZIO, Jean Marie Gustave. Índio Branco. Tradução Júlio Henriques. Lisboa: Fenda, 1989.

RUPPERT, Edward E.; BARNES, Robert D. Zoologia dos invertebrados. Tradução Paulo Marcos Oliveira. 6.ed. São Paulo: Roca, 1996.

SKLIAR, Carlos. Desobedecer a linguagem: educar. Belo Horizonte: Autêntica, 2014.

TADEU, Tomaz. A filosofia de Deleuze e o currículo. Goiânia: Faculdade de Artes Visuais, 2004.

UEXKÜLL, Jacob Von. Dos animais e dos homens. Tradução Alberto Candeias e Anibal Garcia Pereira. Lisboa: Vida e Cultura, 1982. 
VEIGA-NETO. Nietzsche e Wittgenstein: alavancas para pensar a diferença e a Pedagogia. Revista Mutatis Mutandis. v. 2, n. 1. p. 110-121. 2004. Disponível em: <https://dialnet.unirioja.es/descarga/articulo/5012670.pdf>. Acesso em: 20 abr. 2016.

i Bacharel e Licenciada em Ciências Biológicas pela Universidade Federal de Santa Maria (UFSM), Mestre e Doutora em Educação pelo Programa de Pós-Graduação em Educação (PPGE), também pela UFSM. Atualmente é Professora Adjunta I do Departamento de Metodologia do Ensino, do Centro de Educação, da Universidade Federal de Santa Maria, atuando nos cursos de Pedagogia e Educação Especial. Desenvolve estudos na temática de Formação e sua interface nas Filosofias da Diferença. É membro pesquisador do Grupo de Estudos e Pesquisas em Arte, Educação e Cultura (GEPAEC) vinculado ao CNPq.

Enviado em: 30 de maio de 2016.

Aprovado em: 01 de agosto de 2016. 